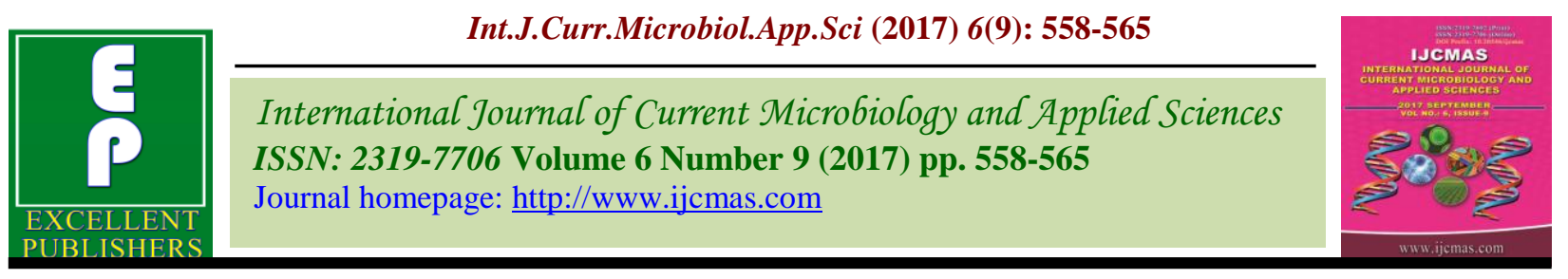

Original Research Article

https://doi.org/10.20546/ijcmas.2017.609.067

\title{
Utilization of Soy Flour and Dehulled Blackgram Flour in the Development of Gluten Free Products
}

\author{
Varsha Rani", Priyanka Rani and Darshan Punia \\ Department of Foods and Nutrition, COHS, CCS Haryana Agricultural University, \\ Hisar, Haryana, India \\ *Corresponding author
}

\section{A B S T R A C T}

Ingestion of gluten and its related peptides leads to malabsorption in the small intestine of patients suffering from celiac disease. The only treatment for celiac patient is the complete

Keywords

Soy flour,

Dehulled

blackgram,

Buckwheat, Gluten

free, Biscuits.

Article Info

Accepted:

04 July 2017

Available Online:

10 September 2017 elimination of wheat or other gluten containing ingredients. This study was aimed to utilize the soy flour and dehulled blackgram flour as a protein source along with gluten free cereals in the development of gluten free products; to carry out their sensory and nutritional evaluation along with shelf life study. Gluten free flour-I was developed using rice flour (50\%), black gram flour (25\%), soy flour (20\%) and buckwheat flour (5g) whereas gluten free flour-II was developed using rice flour (80\%), maize flour (15\%) and buckwheat flour (5g) on fresh weight basis. Matthi, namakpara and sweet and sweet and salty biscuits were prepared with gluten free flour-I whereas noodles and macaroni were prepared with Gluten free flour-II. All the products were organoleptically evaluated by 10 celiac patients from Hisar city using employing 9-Point Hedonic Scale. The products were also evaluated for proximate, micronutrients an anti-nutrient composition in addition to shelf life study. Irrespective of extrusion, frying and baking matthi and namakpara had significantly higher amount of nutrients followed by biscuits and noodle and macaroni. Soy flour, dehulled black gram flour, maize flour, rice flour and buckwheat flour can be successfully used in the development of gluten free biscuits, noodle, macaroni and fried snacks without affecting the sensory qualities of products

\section{Introduction}

The term gluten-free product does not refer to the total elimination of gluten rather some residual amount of gluten is allowed. This amount is however strictly regulated by the Codex Alimentarius Standard which recommends that the product not exceeding 20 milligram of gluten per kilogram should be considered a gluten-free product.

In recent years, market for gluten-free products has been increased as the number of patients with celiac disease is growing day by day worldwide and also in India.

Unfortunately the only way out of celiac disease patients is a lifelong elimination of wheat barley, rye, spelt, and kamut or other cereals products which may contain gluten. However, gluten is an essential structurebuilding protein, contributing to the appearance, crumb structure, and consumer acceptability of many baked products. Never 
the less, market survey clearly demonstrated that there is still a major challenge to improve the quality in terms of nutrients, structure, mouthfeel, consumer acceptability and shelflife of gluten free products (Arendt and Dal Bello, 2008).

Using pulses over gluten free starches can boost the protein, ash, fiber, minerals and vitamins of gluten free products. The high contents of protein in pulses improves the texture of products specially the baked ones. The high content of fibre and moisture in pulses also extends the shelf life of baked products. In last few years various technological efforts have been made to improve the quality of gluten-free products by using flour mixtures (Alvarez-Jubete et al., 2010; Sciarini et al., 2010; Torbica et al., 2010) or non-gluten proteins from egg, milk or soybean (Crockett et al., 2011; Gallagher et al., 2003).

Soybean flour has been an amazing source of protein, unsaturated fatty acids, fiber and calcium. Soy flour can be added up to 50 per cent in any formulation for increasing proteins that lack gluten as it is a leguminous product. In addition to hydrophilic action of soy flour it also inhibits the gluten development while dough preparation; therefore, soy flour should be mixed with other types of flour to get an acceptable volume and structure of bread and other baked products (Sim and Tam, 2001). Soybean proteins isolates and soybean flour have often been used for fortification of bakery products and to improve the protein quality, mechanical behavior and storage life of bakery products (Curic et al., 2007). Dehulled black gram may be considered as another option of increasing nutritional quality of gluten free products.

In gluten-free biscuits the wheat flour needs to be replaced by other ingredients. These ingredients need to replace not only the starch but also the protein fractions. Another advantage in developing gluten-free biscuits is that the formation of a gluten network is not required in a lot of biscuit products. Buckwheat has been used as an important raw material for functional food development because of its functionalities and compounds content, such as proteins, flavonoids and phytosterols (Ötles and Cagindi, 2006). Buckwheat products such as bread, biscuits, snacks, noodles and cookies as well as sprouts have been commercialized and consumed (Hatcher et al., 2008). Keeping in view the above discussed facts and the current demand of market efforts have been made through this research for the development of nutrient dense gluten free snacks.

\section{Materials and Methods}

\section{Procurement of material}

The bulk samples of rice, dehulled black gram, soy flour, buck wheat flour, maize flour and other ingredients used in the preparation of different products were purchased from the local market in a single lot. Moisture free and cleaned rice and dehulled black gram were ground to get flour. All the ingredients were stored in the air tight plastic boxes till further use.

\section{Product development}

Gluten free flour-I was developed using different flour in varying proportions such as rice flour $(50 \%)$, black gram flour $(25 \%)$, soy flour $(20 \%)$ and buckwheat flour $(5 \mathrm{~g})$ whereas gluten free flour-II was developed using rice flour (80\%), maize flour (15\%) and buckwheat flour $(5 \mathrm{~g})$ on fresh weight basis. In both the flours 0.5 per cent of guargum was also added further to improve the cooking quality of flours. Matthi, namakpara and sweet and sweet and salty biscuits were 
prepared with gluten free flour-I whereas noodles and macaroni were prepared with Gluten free flour-II, by using standardized recipes.

\section{Sensory evaluation and shelf life study}

All the products were organoleptically evaluated by 10 celiac patients from Hisar city using employing 9-Point Hedonic Scale. Average of scores for all sensory characteristics, viz., color, appearance, flavor, texture, taste was expressed in terms of overall acceptability.

All the products were stored for a period of two months and these were evaluated for fat acidity, peroxide value and total microbial count at an interval of fifteen days.

\section{Nutritional evaluation}

Protein, fat, crude fibre, ash were determined by the standard method of AOAC (2000). A factor of 6.25 was applied to convert the amount of nitrogen to crude protein. Carbohydrates were calculated by difference method, whereas energy value was calculated by factorial method using factors of 4,4 and 9 for protein, carbohydrates and fat, respectively. For the determination of minerals, samples were digested in di-acid mixture. Calcium, iron and zinc were determined by atomic absorption spectrophotometer according to the method of Lindsey and Norwell (1969), whereas phosphorus was determined colorimetrically by the method of Chen et al., 1956. Phytic acid was determined colorimetrically using a spectrophotometer at $465 \mathrm{~nm}$ (Davies and Reid, 1979). The amount of phenolic compounds was estimated as tannic acid equivalent according to Folin-denis reagent (Swain and Hills, 1956). $\beta$-carotene in sample was separated by column chromatography and estimated colorimetrically (AOAC, 2000).
Gluten content was analysed through hand washing method (AACC, 2000).

\section{Statistical analysis}

Means of standard deviation of different variables/parameters were calculated. Statistically data were analyzed using SPSS statistical package (version 16.0) for windows (SPSS Inc., Chicago IL, USA).

\section{Results and Discussion}

The overall mean scores given to sensory characteristics of gluten free products showed that sweet biscuits, sweet and salty biscuits, macaroni, noodles and matthi were adjudged as "liked moderately" to "liked very much" while namakpara was adjudged as liked slightly by the celiac patients. However, all the products were found to be acceptable by the celiac patients (Table 1). The overall acceptability which was the mean score of colour, appearance, aroma, texture and taste of gluten free products decreased with the advancement of storage period of two months. However, all the products were found to be acceptable up to two months by the celiac patients.

The nutrient composition of two types of flour was compared and it was found that gluten free flour-I contained significantly higher $(p<0.05)$ contents of protein, crude fibre and energy, iron, zinc and calcium that the gluten free flour-II (Tables 2 and 3). Since the gluten free flour-I was developed using as rice flour $(50 \%)$, black gram flour $(25 \%)$, soy flour $(20 \%)$ and buckwheat flour $(5 \mathrm{~g})$, the black gram flour and soy flour contributed a fair amount of nutrients. However, the carbohydrates and $\beta$-carotene contents were higher $(p<0.05)$ in gluten free flour-II since rice is a dominating source of starch and maize had higher content of $\beta$-carotene as compared to other flours. When the nutrient 
composition of products was compared it was found that the nutrient composition of macaroni and noodles did not differ significantly as the more or less same ingredients were used in their preparation and both of these were extruded. Similarly, the nutrient composition of matthi and namakpara also did not differ significantly as both of these were deep fried products and were having significantly higher contents of fat and energy. Sweet biscuits had slightly higher contents of fat, crude fibre, ash, energy and iron than the sweet and salty biscuits.

Irrespective of extrusion, frying and baking matthi and namakpara had significantly higher amount of nutrients followed by biscuits and noodle and macaroni. In a previous study the influence of soy flour on gluten-free dough rheological properties and bread quality was determined. Soy flour was added at 45, 50 and 60 per cent to yellow maize flour basis. No significant differences in the influence of soy flour on dough rheological properties and bread quality were found between the samples with various added amounts of soy flour $(45 \%, 50 \%$, or $60 \%$ ) (Vilmane and straumite, 2014). Wójtowicz et al., (2013) showed a good acceptability of buckwheat enriched snacks, at a level of 30 per cent corn-buckwheat incorporated snacks as an attractive type of appetizer with increased nutritional properties. The biscuits enriched with buckwheat had increased spread ration, hardness and fracturability (Filipčev et al., 2011).

With advancement of storage period the values of fat acidity and peroxide value of flour and products were increased significantly. Increase in fat acidity and peroxide value with advancement of storage period might be due to the breakdown of triglycerides and oxidation of unsaturated fatty acid (Table 4).

Total viable count of gluten free flour and products were determined upto two months of storage on three different types of media (LB, PDA and YEPDA) at $30^{\circ} \mathrm{C}$ under stationery conditions. No total viable count was found in sweet and sweet and salty biscuits at the storage of 15 days whereas it was ranged from $1.0 \times 10^{1}$ to $5.6 \times 10^{1} \mathrm{cfu} / \mathrm{g}$ within matthi, namakpara, noodles, macaroni and gluten free flour being minimum in matthi and maximum in flour and that increased with time. Maximum counts were observed at 45 days in all samples ranged $1.0 \times 10^{4}$ to $3.3 \times 10^{4}$. Yeast colonies were also observed in samples of noodle, macaroni and gluten free flour at 45 days of storage. Fungi were not detected in any of the samples except in gluten free flour at 45 days of storage period (Table 5).

Table.1 Consumer acceptability of wheat free (gluten free) products

\begin{tabular}{|l|r|r|l|l|l|r|}
\hline & Colour & Appearance & Aroma & Texture & Taste & Overall acceptability \\
\hline Noodles & $8.2 \pm 0.2$ & $7.6 \pm 0.2$ & $7.0 \pm 0.2$ & $7.1 \pm 0.3$ & $7.1 \pm 0.2$ & $7.4 \pm 0.4$ \\
\hline Macaroni & $8.0 \pm 0.3$ & $7.8 \pm 0.4$ & $7.6 \pm 0.3$ & $7.2 \pm 0.2$ & $7.4 \pm 0.2$ & $7.6 \pm 03$ \\
\hline Sweet biscuit & $8.0 \pm 0.2$ & $8.4 \pm 0.2$ & $8.4 \pm 0.4$ & $8.0 \pm 0.3$ & $8.2 \pm 0.4$ & $8.2 \pm 0.5$ \\
\hline Sweet and salty biscuit & $8.2 \pm 0.1$ & $8.4 \pm 0.3$ & $8.2 \pm 0.3$ & $8.3 \pm 0.4$ & $8.4 \pm 0.3$ & $8.3 \pm 0.3$ \\
\hline Namakpara & $7.0 \pm 0.2$ & $7.0 \pm 0.1$ & $7.0 \pm 0.2$ & $6.6 \pm 0.2$ & $6.4 \pm 0.3$ & $6.8 \pm 0.2$ \\
\hline Matthi & $7.4 \pm 0.1$ & $7.2 \pm 0.1$ & $7.4 \pm 0.2$ & $7.0 \pm 0.3$ & $7.0 \pm 0.2$ & $7.2 \pm 0.2$ \\
\hline CD $(P<0.05)$ & 0.29 & 0.38 & 0.22 & 0.37 & 0.37 & 0.24 \\
\hline
\end{tabular}

Values are mean \pm SD of responses from a panel of 10 judges 
Table.2 Proximate composition of wheat free (gluten free) products (\%, dry matter basis)

\begin{tabular}{|l|l|l|l|l|l|l|l|}
\hline Products & Moisture & Protein & Fat & Ash & Crude fiber & Carbohydrates & Energy \\
\hline Gluten free flour-I & $4.80 \pm 0.2$ & $21.00 \pm 1.3$ & $1.51 \pm 0.3$ & $1.50 \pm 0.2$ & $2.60 \pm 0.3$ & $72.10 \pm 1.2$ & $378 \pm 9.5$ \\
\hline Gluten free flour-II & $8.30 \pm 0.5$ & $10.53 \pm 0.7$ & $0.60 \pm 0.1$ & $1.09 \pm 0.1$ & $1.15 \pm 0.2$ & $78.56 \pm 1.9$ & $370 \pm 8.2$ \\
\hline Noodles & $6.97 \pm 1.2$ & $9.27 \pm 0.8$ & $1.15 \pm 0.3$ & $0.98 \pm 0.2$ & $1.94 \pm 0.5$ & $81.63 \pm 2.3$ & $374 \pm 10.8$ \\
\hline Macaroni & $6.77 \pm 1.8$ & $9.38 \pm 1.5$ & $1.10 \pm 0.5$ & $0.95 \pm 0.3$ & $1.98 \pm 0.8$ & $79.82 \pm 3.1$ & $367 \pm 13.5$ \\
\hline Sweet biscuit & $1.80 \pm 0.3$ & $18.42 \pm 1.8$ & $21.6 \pm 2.2$ & $3.05 \pm 0.8$ & $2.38 \pm 0.5$ & $55.55 \pm 3.8$ & $488 \pm 14.5$ \\
\hline Sweet and salty biscuit & $1.52 \pm 0.2$ & $19.21 \pm 2.2$ & $20.8 \pm 2.6$ & $2.88 \pm 0.6$ & $2.21 \pm 0.4$ & $53.41 \pm 3.2$ & $478 \pm 13.9$ \\
\hline Namakpara & $1.33 \pm 0.1$ & $20.32 \pm 2.1$ & $22.4 \pm 1.9$ & $4.03 \pm 0.9$ & $2.58 \pm 0 . .3$ & $51.92 \pm 3.1$ & $491 \pm 14.8$ \\
\hline Matthi & $1.50 \pm 0.2$ & $20.00 \pm 1.7$ & $24.6 \pm 2.2$ & $4.45 \pm 0.5$ & $2.96 \pm 0.5$ & $49.45 \pm 2.9$ & $499 \pm 11.5$ \\
\hline CD $(P<0.05)$ & 2.67 & 4.02 & 1.03 & 1.07 & 1.06 & 4.18 & 6.46 \\
\hline
\end{tabular}

Values are mean \pm SD of three independent determinations

Table.3 Micronutrient and anti-nutrient profile of wheat free (gluten free) products

\begin{tabular}{|l|l|l|l|l|l|l|l|}
\hline Products & $\begin{array}{l}\text { Iron } \\
(\mathrm{mg} / 100 \mathrm{~g})\end{array}$ & $\begin{array}{l}\text { Zinc } \\
(\mathrm{mg} / 100 \mathrm{~g})\end{array}$ & $\begin{array}{l}\text { Calcium } \\
(\mathrm{mg} / 100 \mathrm{~g})\end{array}$ & $\begin{array}{l}\text { Phytic acid } \\
(\mathrm{mg} / 100 \mathrm{~g})\end{array}$ & $\begin{array}{l}\text { Polyphones } \\
(\mathrm{mg} / 100 \mathrm{~g})\end{array}$ & $\begin{array}{l}\text { B-carotene } \\
(\mu \mathrm{g} / 100 \mathrm{~g})\end{array}$ & $\begin{array}{l}\text { Gluten } \\
(\mathrm{g} / 100 \mathrm{~g})\end{array}$ \\
\hline Gluten free flour-I & $4.50 \pm 0.2$ & $3.20 \pm 0.2$ & $104.1 \pm 2.0$ & $695.0 \pm 19.97$ & $449.0 \pm 16.6$ & $8.58 \pm 1.5$ & $\mathrm{ND}$ \\
\hline Gluten free flour-II & $1.54 \pm 0.1$ & $1.18 \pm 0.1$ & $25.5 \pm 1.9$ & $254.7 \pm 8.6$ & $211.7 \pm 6.2$ & $15.67 \pm 2.1$ & $\mathrm{ND}$ \\
\hline Noodles & $2.50 \pm 0.3$ & $1.58 \pm 0.5$ & $95.5 \pm 2.2$ & $420.3 \pm 10.2$ & $346.4 \pm 5.8$ & $28.10 \pm 3.6$ & ND \\
\hline Macaroni & $2.61 \pm 0.2$ & $1.41 \pm 0.4$ & $93.6 \pm 3.2$ & $410.3 \pm 8.9$ & $350.7 \pm 5.2$ & $26.53 \pm 3.1$ & ND \\
\hline Sweet biscuit & $1.34 \pm 0.2$ & $1.15 \pm 0.4$ & $26.5 \pm 2.6$ & $204.7 \pm 6.3$ & $171.5 \pm 3.2$ & $6.58 \pm 1.6$ & ND \\
\hline $\begin{array}{l}\text { Sweet and salty } \\
\text { biscuit }\end{array}$ & $1.29 \pm 0.1$ & $1.18 \pm 0.5$ & $28.4 \pm 2.8$ & $184.6 \pm 5.4$ & $175.4 \pm 3.6$ & $6.41 \pm 1.8$ & ND \\
\hline Namakpara & $1.60 \pm 0.2$ & $1.22 \pm 0.3$ & $22.3 \pm 2.4$ & $225.3 \pm 6.3$ & $191.5 \pm 4.1$ & $8.67 \pm 2.1$ & ND \\
\hline Matthi & $1.54 \pm 0.2$ & $1.18 \pm 0.4$ & $27.5 \pm 3.1$ & $219.7 \pm 7.1$ & $186.4 \pm 3.9$ & $10.58 \pm 3.2$ & ND \\
\hline CD $(P<0.05)$ & 1.38 & 1.05 & 4.36 & 6.37 & 5.68 & 2.26 & \\
\hline
\end{tabular}

Values are mean \pm SD of three independent determinations 
Table.4 Fat acidity (mg KOH/100g) and peroxide value (meq/100 g) in wheat free (gluten free) flour and products

\begin{tabular}{|l|l|l|l|l|l|}
\hline Fat Acidity mg KOH/ 100g of sample \\
\hline Products & 0 days & 15 days & 30 days & 45 days & 60 days \\
\hline Gluten free Flour-I & $10.92 \pm 1.2$ & $18.26 \pm 1.2$ & $26.45 \pm 2.1$ & $35.60 \pm 2.4$ & $42.75 \pm 1.9$ \\
\hline Gluten free Flour-II & $9.61 \pm 1.1$ & $16.53 \pm 2.1$ & $24.13 \pm 3.5$ & $32.25 \pm 3.3$ & $38.15 \pm 3.4$ \\
\hline Noodles & $11.40 \pm 0.9$ & $17.59 \pm 1.1$ & $25.30 \pm 1.4$ & $38.12 \pm 1.5$ & $45.60 \pm 2.1$ \\
\hline Macaroni & $12.05 \pm 1.1$ & $17.80 \pm 2.2$ & $24.90 \pm 2.4$ & $36.40 \pm 2.4$ & $46.12 \pm 2.6$ \\
\hline Sweet and salty biscuit & $30.24 \pm 2.7$ & $42.40 \pm 3.2$ & $50.00 \pm 4.0$ & $66.48 \pm 2.8$ & $72.10 \pm 3.0$ \\
\hline Sweet biscuit & $28.61 \pm 2.4$ & $37.58 \pm 2.2$ & $45.40 \pm 2.0$ & $57.18 \pm 3.1$ & $60.08 \pm 3.2$ \\
\hline Namakpara & $50.67 \pm 2.2$ & $62.03 \pm 2.3$ & $70.80 \pm 2.5$ & $85.73 \pm 3.8$ & $92.10 \pm 2.7$ \\
\hline Matthi & $48.54 \pm 1.9$ & $59.40 \pm 2.1$ & $67.90 \pm 2.3$ & $83.10 \pm 3.4$ & $90.38 \pm 3.6$ \\
\hline Peroxide value (meq/100 g of sample & $0.11 \pm 0.01$ & $0.28 \pm 0.02$ & $0.39 \pm 0.01$ & $0.46 \pm 0.01$ & $0.58 \pm 0.01$ \\
\hline Gluten free Flour-I & $0.09 \pm 0.02$ & $0.25 \pm 0.03$ & $0.36 \pm 0.03$ & $0.41 \pm 0.02$ & $0.46 \pm 0.05$ \\
\hline Gluten free Flour-II & $0.28 \pm 0.01$ & $0.46 \pm 0.02$ & $0.60 \pm 0.01$ & $0.75 \pm 0.01$ & $0.88 \pm 0.01$ \\
\hline Noodles & $0.30 \pm 0.01$ & $0.44 \pm 0.01$ & $0.65 \pm 0.01$ & $0.78 \pm 0.01$ & $0.85 \pm 0.01$ \\
\hline Macaroni & $0.30 \pm 0.32$ & $0.68 \pm 0.42$ & $0.89 \pm 0.40$ & $1.05 \pm 0.48$ & $1.20 \pm 0.50$ \\
\hline Sweet and salty biscuit & $0.26 \pm 0.40$ & $0.60 \pm 0.50$ & $0.85 \pm 0.45$ & $0.95 \pm 0.40$ & $1.16 \pm 0.50$ \\
\hline Sweet biscuit & $0.42 \pm 0.06$ & $0.60 \pm 0.08$ & $0.90 \pm 0.05$ & $1.15 \pm 0.05$ & $1.40 \pm 0.04$ \\
\hline Namakpara & $0.35 \pm 0.05$ & $0.50 \pm 0.04$ & $0.80 \pm 0.05$ & $1.06 \pm 0.04$ & $1.38 \pm 0.08$ \\
\hline Matthi
\end{tabular}

Values are mean \pm SD of three independent determinations

Table.5 Total microbial count of wheat free (gluten free) flour and products at different storage period

\begin{tabular}{|l|l|l|l|}
\hline \multirow{2}{*}{ Products } & \multicolumn{3}{|c|}{ Total viable count (cfu/g) } \\
\cline { 2 - 4 } & $\mathbf{1 5}$ days & $\mathbf{3 0}$ days & $\mathbf{4 5}$ days \\
\hline Gluten free Flour-I & $5.6 \times 10^{1}$ & $6.3 \times 10^{3}$ & $1.3 \times 10^{4}$ \\
\hline Gluten free Flour-II & $5.3 \times 10^{1}$ & $6.0 \times 10^{2}$ & $1.2 \times 10^{3}$ \\
\hline Noodle & $1.2 \times 10^{1}$ & $1.6 \times 10^{2}$ & $1.2 \times 10^{4}$ \\
\hline Macaroni & $1.4 \times 10^{1}$ & $1.6 \times 10^{2}$ & $3.2 \times 10^{4}$ \\
\hline Sweet and salty & - & $1.1 \times 10^{2}$ & $1.5 \times 10^{4}$ \\
\hline Sweet biscuit & - & $1.2 \times 10^{2}$ & $1.0 \times 10^{4}$ \\
\hline Namakpara & $1.5 \times 10^{1}$ & $1.1 \times 10^{2}$ & $1.6 \times 10^{4}$ \\
\hline Matthi & $1.0 \times 10^{1}$ & $1.0 \times 10^{2}$ & $3.3 \times 10^{4}$ \\
\hline
\end{tabular}


It may be concluded from this research that soy flour, dehulled black gram flour, maize flour, rice flour and buckwheat flour can be successfully used in the development of gluten free biscuits, noodle, macaroni and fried snacks without affecting the sensory qualities of products along with good shelf life. Addition of soy flour and dehulled black gram flour has improved the nutrient profile of gluten free products specially the protein and mineral contents. All the products were liked and acceptable by the celiac patients. Adding variety to the limited food choice may be the cost effective way to improve the health and nutritional status of celiac patient.

\section{References}

AACC, 2000. Approved methods of AACC. American Association of Cereal Chemists, Ed. St. Paul, MN.

Alvarez-Jubete, L., Auty, M., and Arendt, E.K. 2010. Baking properties and microstructure of pseudocereal flours in gluten-free bread formulations. European Food Research and Technology, 230, 437-445. DOI: 10.1007/ s00217-009-1184-z.

AOAC, 2000. Official Methods of Analysis. Association of Official. Analytical Chemists, Washington, D.C. USA.

Arendt, E.K., and Dal Bello F (eds) 2008. Gluten-free Food and Beverages. Academic Press - Elsevier. ISBN978-012- 373739-7.

Chen, P.S., Tosibara TY and Warner H. 1956. Micro determination of phosphorus. Analytical Chemistry 28:1756-1759.

Crockett, R., Ie, P., and Vodovotz, Y. 2011. Effects of soy protein isolate and egg white solids on the physicochemical properties of gluten-free bread. Food Chemistry, 129, 84-91. DOI: 10.1016/j.foodchem.2001.04.030.

Curic, D., Novotni, D., Tusak, D., Bauman, I., and Gabric, D. 2007. Gluten-free bread production by the corn meal and soybean flour extruded blend usage. Agriculture Conspectus Scientificus, 72(3), 227-232.

Davies, N.T., and Reid H. 1979. An evaluation of phytate, zinc, copper, iron and magnesium content and availability from soya-based textured vegetables. British journal of nutrition 41:579.

Filipčev, B., Šimurina O., Sakač M., Sedej I., Jovanov P., Pestorić M., BodrožaSolarov M., Feasibility of use of buckwheat $\mathrm{fl}$ our as an ingredient in ginger nut biscuit formulation. Food Chem., 2011, 125, 164-170.

Gallagher, E., Gormley, T.R., and Arendt, E.K. 2003. Crust and crumb characteristics of gluten free breads. Journal of Food Engineering, 56, 153161. DOI: 10.1016/S02608774(02)00244-3.

Hatcher, D.W., You S., Dexter J.E., Campbell C., Izydorczyk M.S., Evaluation of the performance of fl ours from cross - and self - pollinating Canadian common buckwheat (Fagopyrum esculentum Moench) cultivars in soba noodles. Food Chem., 2008, 107, 722-731.

Laila Vilmane, L., Straumite, E. 2014. The use of soy flour in yellow maizeamaranth gluten-free bread production. Proc. Latv. Univ. Agr, 31(326):1-11.

Lindsey, W.L., Norwell, M.A. 1969. A new DPTA-TEA soil test for zinc and iron. Agronomy Abstract 61:84.

Ötles, S., Cagindi Ö., Cereals based functional foods and nutraceuticals. Acta Sci. Pol. Technol., 2006, 5, 107112.

Sciarini, L.S., Ribotta, R.D., Leon, A.E., and Perez, G.T. 2010. Influence of glutenfree flour and their mixtures on batter properties and bread quality. Food and Bioprocess Technology, 3, 577-585. DOI: $10.1007 / \mathrm{s} 11947-008-0098-2$.

Sim, J., and Tam, N. 2001. Eating qualities of 
muffins prepared with $10 \%$ and $20 \%$ soy flour. Journal of Nutrition in Recipe and Menu Development, 3(4), 25-34. DOI: 10.1300/J071v03n02_03.

Swain, J., and Hills WE. 1956. The phenolic constituents Pramus domestical. The qualitative analysis of phenolic constituents. Journal of Science food and agriculture 10: 63-68.

Torbica, A., Hadnadev, M., and Dapčevic, T. 2010. Rheological, textural and sensory properties of gluten-free bread formulations based on rice and buckwheat flour. Food Hydrocolloids, 24, 626-632. DOI: 10.1016./j.foodhyd.2010.03.004.

Wójtowicz, A., Kolasa A., Mościcki L., Influence of buckwheat addition on physical properties, texture and sensory characteristics of extruded corn snacks. Pol. J. Food Nutr. Sci., 2013, 63,239244.

\section{How to cite this article:}

Varsha Rani, Priyanka Rani and Darshan Punia. 2017. Utilization of Soy Flour and Dehulled Blackgram Flour in the Development of Gluten Free Products. Int.J.Curr.Microbiol.App.Sci. 6(9): 558-565. doi: https://doi.org/10.20546/ijcmas.2017.609.067 